\title{
WAGE, PRICE AND UNEMPLOYMENT DYNAMICS IN THE SPANISH TRANSITION TO EMU MEMBERSHIP*
}

\section{Katarina Juselius and Javier Ordóñez ${ }^{* *}$}

WP-EC 2008-09

Correspondencia a: J. Ordóñez: Department of Economics, Jaume I University. Campus de Riu Sec. 12080 Castellón (Spain). E-mail: jmonfort@eco.uji.es

Editor: Instituto Valenciano de Investigaciones Económicas, S.A.

Primera Edición Mayo 2008

Depósito Legal: V-2458-2008

Los documentos de trabajo del Ivie ofrecen un avance de los resultados de las investigaciones económicas en curso, con objeto de generar un proceso de discusión previo a su remisión a las revistas científicas.

\footnotetext{
* The authors gratefully acknowledge the financial help from the Instituto Valenciano de Investigaciones Económicas (IVIE) and the CICYT project SEJ2005-01163.The usual disclaimer applies.

** K. Juselius: University of Copenhagen. J. Ordóñez: Department of Economics, Jaume I University.
} 


\title{
WAGE, PRICE AND UNEMPLOYMENT DYNAMICS IN THE SPANISH TRANSITION TO EMU MEMBERSHIP
}

\author{
Katarina Juselius and Javier Ordóñez
}

\begin{abstract}
This paper provides an empirical investigation of the wage, price and unemployment dynamics that have taken place in Spain during the last two decades. The aim of this paper is to shed light on the impact of the European economic integration process on Spanish labour market and the convergence to a European level of prosperity. We find some important lessons to be learnt from the Spanish experience that should be relevant for the new member states. First, high competitiveness in the tradable sector seems crucial for the real and nominal convergence to be successful. The increase in consumption wages and consumer prices as a result of the BalassaSamuelson effect should not be allowed to exceed the improvement in productivity. Second, before fixing the real exchange rate it seems crucial that it is on its sustainable (competitive) purchasing power parity level. Third, there does not seem to be a short-cut to a European level of standard of living: the path to sustainable prosperity seems to follow the path of productivity improvement. Forth, excessive real wage increases seem to lead to increasing unemployment, slowdown in productivity growth, higher interest rates, and loss of competitiveness. On the other hand, the access to the European market and the possibility of increased export demand is likely to speed up the convergence process as long as competitiveness is not eroded by excess wage increases.
\end{abstract}

Key words: Balassa-Samuelson effect, nominal and real convergence, unemployment dynamics, purchasing power parity, cointegrated VAR.

Classification JEL: C32, E24.

RESUMEN

El presente trabajo analiza la dinámica de los salarios, precios y desempleo habida en España durante las últimas dos décadas. El objetivo es mejorar nuestra compresión sobre el impacto que el proceso de integración europeo pudo tener sobre el mercado de trabajo español y el proceso de convergencia hacia un nivel de prosperidad similar al europeo. Nuestros resultados apuntan a que de la experiencia española se podrían extraer conclusiones de interés para los países recientemente incorporados. En primer lugar, una elevada competencia en el sector de los bienes comercializables aparece como necesaria para que se produzca la convergencia tanto nominal comercial. El incremento en los salarios y los precios como resultado del efecto Balassa-Samuelson no deberían exceder los incrementos en productividad. En segundo lugar, antes de fijar los tipos de cambio es necesario que éste se encuentre en un nivel sostenible (competitivo) de capacidad de compra. En tercer lugar, no parece existir un "atajo" para alcanzar un nivel de vida similar a la media europea: el camino hacia una prosperidad sostenible sigue la senda del crecimiento de la productividad. En cuarto lugar, demandas salariales excesivas conllevan un incremento del empleo, una caída en el crecimiento de la productividad, tipos de interés más elevados y pérdida de competitividad. Por otro lado, el acceso a los mercados europeos y la posibilidad de aumentar las exportaciones favorece la convergencia a menos que la competitividad no se vea erosionada por demandas salariales excesivas.

Palabras claves: efecto Balassa-Samuelson, convergencia real y nominal, dinámica del desempleo, paridad del poder de compra, VAR cointegrado. 


\section{Introduction}

The aim of this paper is to shed light on the dynamic adjustment processes of Spanish prices, wages and unemployment in the transition from a relatively poor outsider to a prosperous EU insider. Spain is the largest of the four "peripheral" countries that joined the European Union and her experience has been successful in curbing inflation and promoting economic growth and employment. At the beginning of the sample period the Spanish standard of living was low compared to the EC countries, at the end it was more or less in line with the same countries. The question is whether there are useful lessons to be learnt from studying the historical changes in the macroeconomic mechanisms in Spain during the convergence period. If such knowledge is used to better foresee (and hopefully avoid) future problems for new member states, the benefits could be substantial.

Our sample begins in 1983:1, a few years after the EMS regime became effective with 11 member states adopting the ERM exchange rate arrangement. Spain did not become a member in the first round: the Spanish inflation was too high and the economy suffered from various structural imbalances. When our sample starts, the Spanish purchasing power parity (PPP) was at a much lower level than most of the more prosperous EEC member states. When our sample ends in 2007:3, Spain has achieved a PPP level similar to the other European member states. Several factors can potentially explain this development.

First, the Balassa-Samuelson effect (Balassa, 1964, Samuelson, 1964) explains the fact that the real exchange rates of less wealthy economies generally deviate substantially from the ones of the more wealthy economies. In short it says that a country's general price level is positively related to the level of per capita income. The rational for this is that productivity in the tradable sector tends to be higher in richer than in poorer countries, whereas productivity in the nontradable sector is more similar. Wage levels in the tradable sector influence wages in the nontradable sector, so nontradables tend to be more expensive in rich countries. When domestic wages increase as a result of productivity growth, foreign competition is likely to prevent price increases in the tradable sector, whereas not in the nontradable sector. This will generally make consumer prices increase more than producer prices. Therefore, positive co-movements between labor productivity and the price wedge (the difference between consumer and producer prices) is likely to reflect product market competition (Boeri, et. al. 2001). This is illustrated in Figure 1, upper panel, where the price wedge and the productivity both have grown up to 2004 after which the price wedge is declining. Thus, the Balassa-Samuelson catching-up period might have ended around 2004.

Second, in a globalized and competitive world real wage increases in excess of productivity are likely to jeopardize product market competitiveness in 
highly exposed industries. Figure 1, lower panel, shows that Spain experienced excessively high real wage growth rates in 1986-1992. The subsequent analysis will show that this caused enterprises to increase labor productivity by reducing employment.

Figure 1: The development of the price wedge and the productivity (upper panel) and the real exchange rate over the sample period
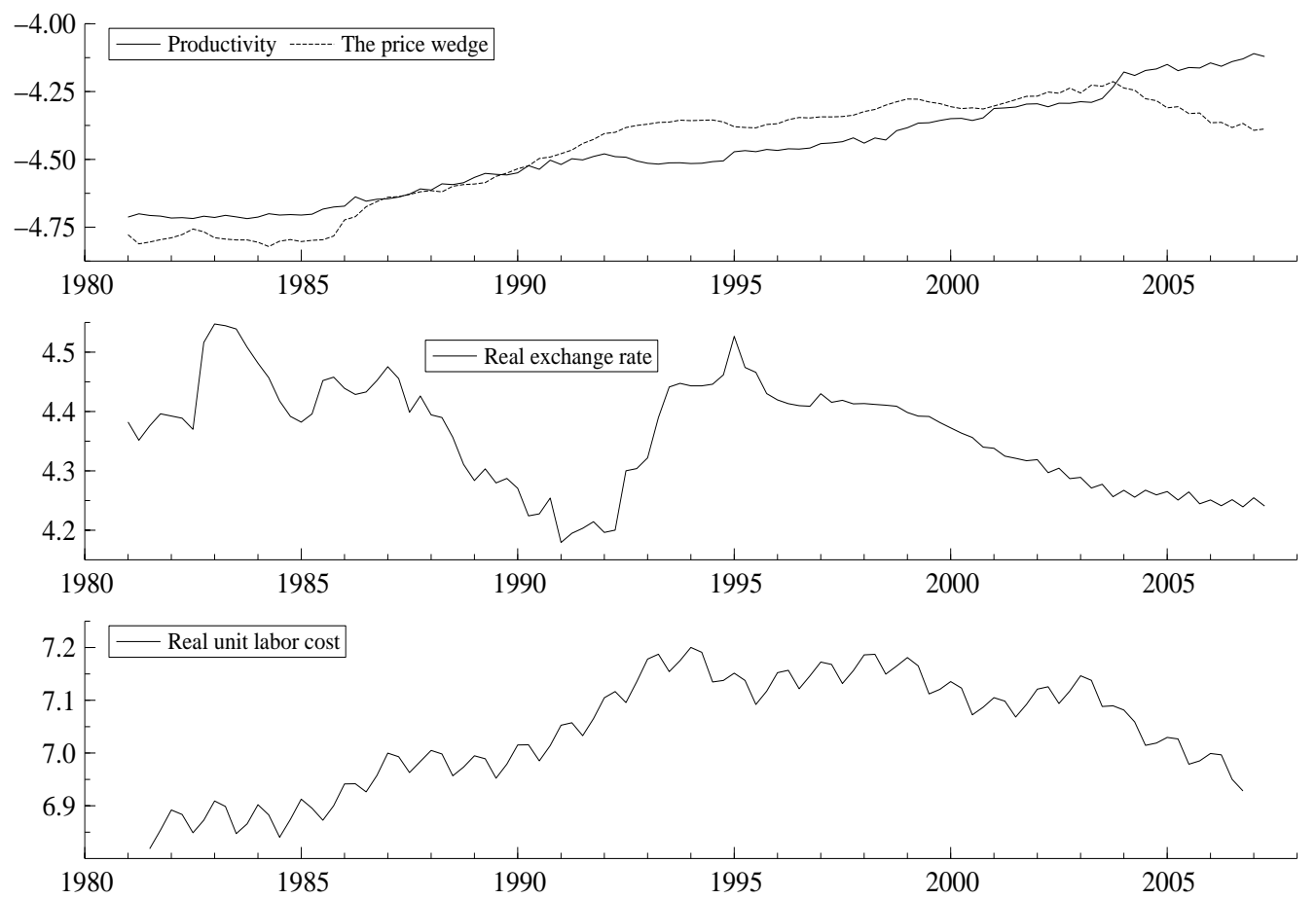

Third, the long swings in the real exchange rates visible in Figure 1, middle panel, are likely to have strongly influenced the price adjustment mechanism in the transition period. Frydman and Goldberg (2007) have demonstrated that such long swings away from historical benchmark values can be the outcome of fully rational individuals attempting to forecast the exchange rate based on imperfect knowledge (not knowing the right model, nor the most relevant explanatory variables). Furthermore, they show that the real long-term interest rate differential is likely to exhibit similar long swings as in real exchange rates. Thus, we would expect the transition dynamics to be strongly influenced by the persistent movements in the real exchange rates as well as the long-term interest rate.

The empirical challenge is, therefore, to identify the Balassa-Samuelson effect, the increased product market competition, and the effect of imperfect knowledge in the foreign exchange market on the wage-, price, and unemployment dynamics in Spain and how these have interacted to secure the path 
towards a common European purchasing parity level. This will be done based on a detailed cointegrated VAR analysis of a dynamic interdependent system consisting of consumer and producer prices, wages, productivity, unemployment, interest rates and exchange rates. To investigate the Balassa-Samuelson effect and product market competition on the system we first perform a VAR analysis on the basic domestic variables and then expand the model with the real exchange rates and the long-term interest rate to isolate the effect of speculative (imperfect knowledge) behavior on the labor market dynamics.

The remainder of the paper is organized as follows. In section 2, we provide the institutional background for the economic development of Spain as an EU outsider to a prosperous EMU insider. Section 3 discusses a theoretical background for the relations to be tested. Section 4 introduces the empirical approach and presents some test results on the pulling and pushing properties of the model. Section 5 reports a sequential cointegration analysis of the wage, price and unemployment structure and Section 6 the dynamics of the pulling and pushing forces that have brought Spain to a sustainable European purchasing power parity. Section 6 concludes.

\section{Four stages in the transition towards the EMU}

Spain's commitment to move towards the European monetary union in 1986 initiated an adjustment process towards the European productivity level and, gradually, towards a European purchasing power parity level. Over this transition period, one can broadly identify four regimes describing various aspects of the convergence towards the European level. Some regimes were very successful in terms of growth and prosperity, others less so. First, we shall briefly discuss the basic characteristics of the four regimes.

The first sub-period, 1983 - 1986, describes the last years of a long period of serious structural imbalances, characterized by slowdown in productivity growth, high unemployment rates, real wage growth in excess of productivity growth, and high inflation rates. The roots of these problems can be traced back to the oil crisis in the seventies which hit the Spanish economy very severely ${ }^{1}$. This shock increased product prices and decreased labour demand. Downward wage rigidities prevented the necessary real wage adjustment that could have restored the demand for labor. Strong bargaining power by labor unions resulted in wage claims which substantially exceeded productivity growth. The result was stagflation: high rates of inflation and unemployment ${ }^{2}$ and modest real GDP growth rates were pervasive until the decision to join the EMS in 1986.

\footnotetext{
${ }^{1}$ In 1977 approximately $66 \%$ of the consumed energy was imported.

${ }^{2}$ From 1977 to 1985 Spain experienced a huge employment reduction (about two million jobs) which raised the unemployment rate to $21 \%$ of the labour force.
} 
The second sub-period, 1987 - 1993, describes the early EMS period ending with the crisis in 1992. Intra-European trade was enhanced by the removal of trade barriers, by financial deregulation and by gradually fixing the exchange rates. In most of this period Spain experienced high real growth, declining unemployment rates, but also raising real wages and consumer prices, very much in accordance with the Balassa-Samuelson effect. In the first years Spain adopted the broad bands of the Exchange Rate Mechanism $( \pm 6 \%)$ and from 1989 the narrow bands $( \pm 2.25 \%)$. Even though productivity continued to increase, there were signs of a slowdown at the end of the period, indicating that productivity had begun to catch up with the EU level. With high real interest rates, Spain experienced large inflows of foreign capital, and the consequent appreciation of the Spanish peseta eroded competitiveness in the export sector. At the same time, a steady increase of real wages in excess of productivity resulted in a serious loss of competitiveness. Because the membership in the ERM prevented competitive devaluations, the economy got stuck in external and internal imbalances that gradually became unsustainable. This was spotted by the financial market which launched a speculative attack on the Spanish peseta in September 1992 forcing Spain to leave the narrow bands of the ERM and to devalue the peseta. ${ }^{3}$

The third sub-period, 1993-1998, describes a restructuring and consolidation regime starting from the speculative attack in September 1992 and ending with the launch of the Euro in 1999. During the first years, the floating peseta brought the real exchange rate back to its pre-1987 level. The market labour reforms of 1994 and 1997 contributed to reduce labor union bargaining power. Excessive wage claims were avoided and competitiveness was restored. From 1996 onwards, almost ten years after the EU membership, unemployment rates started to decline more permanently. In 1999, Spain finally joined EMU as a full member.

The fourth sub-period, 1999-2007, describes the more recent period of full EMU membership during which the Spanish economy seems to have done utterly well: productivity has increased, inflation has remained at the EU level, real interest rates have came down and economic activity and employment have improved.

\section{Theoretical background}

In the following capital letters will denote variables in levels, lower case letters will denote logarithmic values, $X_{t}^{e}$ generally stands for agents' expectation at

\footnotetext{
${ }^{3}$ The Spanish currency was first devaluated by 5\% in September 1992 and further $6 \%$ and $8 \%$ in November 1992 and May 1993 respectively. The last devaluation took place in March 1995 by a $7 \%$.
} 
time $t$ of a a future value $X_{t+k}$, and $v_{i, t},=1,2, .$. stands for a residual in a long-run relation.

We first introduce the basic economic relationships in a general framework. The level of output, $Y$, is a function of labor, $L$, capital, $K$, and total factor productivity, $\tau$

$$
Y_{t}=Y\left(L_{t}, K_{t}, \tau_{t}\right)
$$

The demand for domestic goods is a function of foreign prices in domestic currency, $P_{I, t}$, domestic prices, $P_{y, t}$, and other real factors, $Z_{t}$ to be subsequently specified:

$$
D_{t}=D\left(P_{y_{t}}, P_{I, t}, Z_{t}\right)
$$

The domestic output price depends on wage costs, $W$, import prices in domestic currency, $P_{I}$, and $Z$ :

$$
P_{y, t}=P_{y}\left(W_{t}, P_{I, t}, Z_{t}\right)
$$

The implied labor demand function then becomes:

$$
L_{t}=L\left(P_{y}\left(W_{t}, P_{t}^{I}, Z_{t}\right), P_{I, t}, K_{t}, \tau_{t}\right)
$$

The labor supply depends on wages and $Z$ :

$$
S_{t}=S\left(W_{t}, Z_{t}\right)
$$

Based on standard economic theory there exists no involuntary unemployment but allowing for search costs, imperfect knowledge, different kinds of menu costs, etc. unemployment can deviate in the short run from a constant rate, the natural rate of unemployment. However, as illustrated in Figure ??, upper panel, the Spanish unemployment rate has exhibited a pronounced persistence in this period suggesting non-stationarity instead of stationarity. The lower part of the figure shows that inflation rate has been steadily declining during the period. Also, Figure 1, lower panel, shows that the wage share $\left(w-p_{y}-q\right)$ increased steadily up to the speculative attack in 1993, and then stayed almost constant until 1999, after which it started to decline. The increase in real unit labor cost in 1986-1992 forced Spanish enterprises to improve labor productivity, often by layoffs and reduced hires. Altogether, persistent deviations from fundamental benchmark values rather than fast equilibrium correction, seem to have characterized most of the investigated sample pe- 
riod. Strong labor unions and centralized wage formation, high search costs, low mobility, and increasing globalization have been offered as explanations. Whatever the explanation, standard models need to be modified to be able to account for these empirically strong features of the data.

Figure 2: The graphs of unemployment rate (upper panel) and the quarterly inflation rate (lower panel)

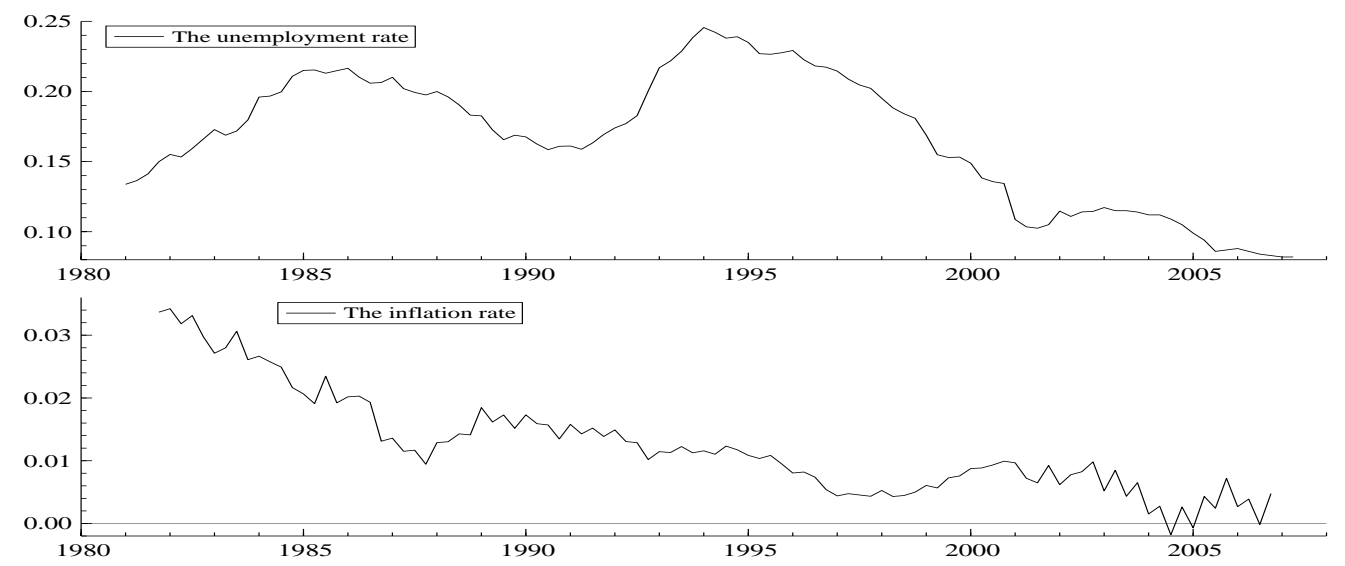

\subsection{Centralized wage bargaining and an aggregate wage relation}

In most of the investigated period Spanish wages have been set by centralized wage bargaining with the bargaining power of the unions strongly affected by the unemployment rate. A proposed pay rise by the labor union reflects generally a trade-off between a higher consumption wage against a lower employment as a result of an increase in the real product wage increase (Moene et. al., 1993). Whether the pay rise is accepted or not by the employers' organizations is assumed to depend on the trade-off between future profits and firm competitiveness against the increased risk of a union strike. In this vein, wage formation can be seen as a struggle over the mark-ups, where expectations of future outcomes of key variables play a significant role. Under this assumption, unions strive to maximize their share of the productivity increase with productivity defined as output per employment, $c_{t}=y_{t}-l_{t} \cdot{ }^{4}$ The employers' unions attempt to maximize the mark-up on unit costs, defined here as $-\left(w_{t}-p_{y, t}-c_{t}\right)$, at the same time accounting for the anticipated effect of the real product wage increase on its competitiveness. The mark-up is assumed to be a function of the expected real exchange rate, $q_{t}^{e}=\left(s-p^{f}-p_{y}\right)_{t}^{e}$, where $s$ is

\footnotetext{
${ }^{4}$ In this section all variables, except interest rates, are expressed in logarithms.
} 
the nominal exchange rate, $p^{f}$ is the foreign price level, of expected inflation, $\Delta p_{t}^{e}$, and expected real interests, $R_{t}^{r^{e}}$, i.e:

$$
\left(w_{t}-p_{y, t}-c_{t}\right)=f\left(q_{t}^{e}, R_{t}^{r^{e}}, \Delta p_{t}^{e}\right)+v_{1, t}
$$

where $f_{q^{e}}>0$ implies a lower mark-up as a result of a real appreciation (see Phelps, 1994), $f_{R^{r e}}>0$ implies a lower mark-up as a result of a rise in the real interest rate, and $f_{\Delta p^{e}}>0$ indicates a negative effect on the markup from inflation (see Banerjee and Russel, 2005).

The labor unions attempt to maximize the purchasing power for their members by increasing the real consumer wage, $\left(w_{t}-p_{c, t}\right)$ conditional on the level of productivity, $c_{t}$, and accounting for the expected effect on the unemployment rate, $U_{t}^{e}$, and expected inflation rate, i.e.:

$$
\left(w_{t}-p_{c, t}-c_{t}\right)=g\left(U_{t}^{e}, \Delta p_{t}^{e},\right)+v_{2, t}
$$

where $g_{U^{e}}<0$, and $g_{\Delta p^{e}}>0$. Expected values, $X_{t}^{e}$ are assumed to deviate from the actual values $X_{t}$ with a stationary error. Under this assumption, the cointegration properties should not change when actual rather than expected values are used.

\subsection{The price wedge, productivity and unemployment}

The price wedge $\left(p_{c, t}-p_{y, t}\right)$ has often been found highly relevant in empirical wage relations and deserves some theoretical justification. First, different bargaining structures imply different terms of trade between a rise in the real consumption wage and the real product wage (Moene eet al., 1993). For example, if wages increase in one employment sector, but not in the others, then under constant mark-up pricing output price will increase but the impact on the consumer price will be smaller. Second, the extent of product market competition is likely to be even more important for the price wedge. If an industry is exposed to a high degree of foreign competition, product prices cannot be raised by much even though the domestic wages rise. In this case we would expect pricing-to-market to characterize pricing behavior. Since prices on non-tradables are more likely to increase after a wage rise, the price wedge is, however, likely to increase. Third, because the consumption basket also contain imported goods and services, the prices of these will also influence the consumer prices so that a nationwide wage rise can increase real consumption wage more than the real product wage if import prices remain unchanged or decrease. All this leads to the important question of where in the system the adjustment takes place after a wage rise (Boeri, et al., 2001). 
Subtracting (1) from (2) gives an expression for the relationship between the price wedge and the main determinants of the negotiated wage:

$$
p_{c, t}-p_{y, t}=a_{1}+a_{2} \Delta p_{c t}+a_{3} U_{t}+a_{4} R_{t}^{r}+a_{5} q_{t}+v_{3, t}
$$

When $v_{5, t}$ is stationary there are several possible cointegration specifications which are consistent with (3). For example, (3) might consist of two irreducible cointegrating relations, one between $\left(p_{y, t}-p_{c, t}\right), R_{t}^{r}$ and $q_{t}$ and the other between $U_{t}$ and $\Delta p_{t}$. In this case, the five variables would share three common stochastic trends. If there are fewer common stochastic trends then there would be correspondingly more cointegration. Of particular interest here is whether $U_{t}$ and $\Delta p_{c, t}$ are cointegrated as a Phillips curve relation with a constant NAIRU ${ }^{5}$ :

$$
\Delta p_{c t}=a_{6}+a_{7} U_{t}+v_{4, t}
$$

where $a_{7} \leq 0$ and $v_{4, t} \sim I(0)$. If, on the other hand $v_{4, t} \sim I(1)$ in (4) we need to be combine it with some of the other variables in (3), for example the interest rate as suggested by Phelps (1994):

$$
\Delta p_{c t}=a_{8}+a_{9} U_{t}+a_{10} R_{t}+v_{5, t}
$$

where $a_{9} \leq 0, a_{10} \geq 0$ and $v_{5, t} \sim I(0)$. In this case the NAIRU would be a function of the firm's cost of capital.

\subsection{Labor productivity and unemployment}

With the deregulation of capital movements and the adoption of the narrow bands of the EMS in 1989, Spain became more integrated in the EU market, which implied a strong pressure on the Spanish industry to be competitive. In particular, the high real wage increases in the period 1986-1992 aggravated competition for enterprises, the output prices of which often were on (or above) the competitive foreign trade level. Thus, the industry had the possibility to (1) reduce employment until the marginal cost equals the competitive price, (2) increase labor productivity, or (3) close down the industry (Boeri et al. 2001). The subsequent empirical analysis suggests that the first two options were highly relevant in this period.

\footnotetext{
${ }^{5}$ Note that the Phillips curve is defined here to be a relation between nonstationary variables.
} 
Regarding option (2), we need to distinguish between a rise in labor productivity due to technological progress and to elimination of previous slack in the work process. The latter includes measures such as increasing the work pace, eliminating coffee breaks, and generally making employees run faster. Such an increase in productivity implies that the same output can be produced with less labour and, therefore, could be accompanied by layoffs and/or no new hires.

To distinguish between the two possibilities, we will approximate the longterm technology growth with a linear trend, and the productivity increase due to elimination of slack with the trend-adjusted productivity. Recalling that $c_{t}=y_{t}-l_{t}$ we note that productivity can increase both as a result of an increase in aggregate output with constant employment and a decrease in employment with constant GDP. If $\left(c_{t}-b_{1} t\right)$ is empirically $I(1)$ and cointegrates with unemployment (similarly as in Juselius, 2003 and 2007, Chapter 20) it will be interpreted as evidence that improvements in labor productivity have been achieved by layoffs and/or reduced hires. In this case, output prices are not likely to increase as much as wages, so real consumer wages will increase more than real product wages corrected for productivity and $\left(p_{c, t}-p_{y, t}\right)$ will increase.

Based on the above, the unemployment rate is likely to be co-moving with trend-adjusted productivity and the consumer-output price wedge. This leads to the following relation:

$$
U_{t}=a_{11}+a_{12}\left(c_{t}-b_{1} t\right)+a_{13}\left(p_{c, t}-p_{y, t}\right)+v_{6, t},
$$

where $a_{12} \geq 0, a_{13} \geq 0$ and $v_{6, t} \sim I(0)$.

Thus, if the above hypotheses are correct we would expect labor productivity, rather than the real product wage, to be adjusting to (6). Naturally, this kind of improvement in productivity seems only possible up to the point where there is no slack left to eliminate and where increased work pressure becomes counterproductive. In such a situation we would expect outsourcing, rather than improvement in domestic labor productivity, as a consequence of a wage increase in excess of productivity.

\subsection{Inflation adjustment relations}

When inflation rate is empirically $I(1)$ (as in our case), prices are $I(2)$. Under long-run price homogeneity, relative prices are generally I(1) and we would expect cointegration between the latter and inflation rate (Juselius, 2007, Chapters 16-18). In the present application, inflation rate could potentially be

cointegrated with the domestic price wedge, the foreign price wedge and/or real wages. 


$$
\Delta p_{c t}=a_{14}+a_{15}\left(p_{c}-p_{y}\right)_{t-1}+a_{16}\left(p_{c}-p^{f}-s\right)_{t-1}+a_{17}\left(w-p_{c}\right)_{t-1}+v_{7, t}
$$

where $\left(p_{c}-p^{f}-s\right)=-q_{t}, v_{7, t} \sim I(0)$ and $a_{15} \leq 0, a_{16} \leq 0, a_{17} \geq 0$ implies equilibrium correction of inflation rate. The magnitude and significance of the coefficients signals which part of the system has been most important for the long-run inflation path.

\section{The empirical model}

The purpose of the empirical analysis is to extract as much information as possible from the data at the background of the broadly defined theoretical relations discussed in the previous section. In accordance with the chosen econometric methodology, we will interpret the results in terms of the dynamics of the pulling and pushing forces and how these are reflected in the institutional changes over this period.

\subsection{Defining the model}

The quarterly data used in this analysis are defined by:

$$
x_{t}^{\prime}=\left[\omega_{t}^{r}, c_{t}, u_{t}, \Delta p_{t}, p p_{t}, q_{t}, R_{t}^{l}\right] \quad \mathrm{t}=1983: 3 \text { to } 2007: 3
$$

where $\omega_{t}^{r}$ is the $\log$ of real wage measured as the hourly wage in manufacturing deflated by the consumer price index; $c_{t}$ is the log of labour productivity, calculated as real GDP per total employment; $u_{t}$ is the unemployment rate; $\Delta p_{t}$ is the first difference of the log of the consumer price index and measures inflation; $p p_{t}$ is the price wedge and corresponds to the difference between consumer price index and producer price index, both expressed in logs; $q_{t}$ stands for the log of the real exchange rate of the Spanish peseta relative to the German mark and is expressed in units of national currency per foreign currency; finally, $R_{t}^{l}$ is the ten years government bond yield. The long-term interest rate is divided by 400 to make the estimated coefficients comparable with logarithmic quarterly changes.

The empirical analysis is based on the following $p$ dimensional $\operatorname{VAR}(2)$ model with a linear trend restricted to be in the cointegration relations:

$$
\Delta x_{t}=\Gamma \Delta x_{t-1}+\alpha \beta^{\prime} x_{t-1}+\alpha \beta_{1} t+\alpha \delta_{0} D s_{t}+\Phi_{1} D p_{t}+\Phi_{2} D q_{t}+\Phi_{21} D q 02_{t}+\mu_{0}+\varepsilon_{t}
$$


where $\alpha$ is $p \times r$ adjustment coefficients, $\beta^{\prime} x_{t}$ is $r$ cointegration relations, $\beta_{1}$ is an $r \times 1$ vector of trend coefficients, $\mu_{0}=\alpha \beta_{0}+\alpha_{\perp} \gamma_{0}$ is a $p \times 1$ vector of constant terms, with $\beta_{0}$ an intercept in the cointegration relations and $\gamma_{0}$ the slope of linear trends in the data, and $\delta_{0}$ measures mean shifts in $\beta^{\prime} x_{t}{ }^{6}$ given by $D s_{t}=\left[D S 861_{t}, D S 923_{t}, D S 991_{t}\right]$, where $D S x x y_{t}=1$ for $t \geq 19 x x$ :y, otherwise 0 . In addition, there are five permanent impulse dummies, $D p_{t}=\left[D p 861_{t}, D p 923_{t}, D p 991_{t}, D p 951_{t}, D p 011_{t}\right]$ where $D P x x y$ is 1 in 199xx:y, 0 otherwise, $D q_{t}$ contains seasonal dummies and $D q 02_{t}$ is a set of seasonal dummies starting from 2002:1. The latter is needed because of a redefinition of CPI prices in 2002:1.

The step dummy DS861 accounts for the Spanish entry in the EU, DS923 for the EMS crisis in September 1992, and DS991 for the beginning of the common monetary policy. The first three impulse dummies account for the large shock at the beginning of the three regimes in 1986:1, 1992:3 and 1999:1. The last two account for a change in policy from monetary to inflation targeting in 1995:1 and a change in the employment survey in 2001:1 which implied a reduction of the official unemployment by around $2.5 \%$.

The common trends representation of (8) is given by:

$$
x_{t}=C \sum_{i=1}^{t}\left(\varepsilon_{i}+\mu_{0}+\Phi_{1} D p_{i}\right)+C^{*}(L)\left(\varepsilon_{t}+\mu_{0}+\mu_{1} t\right)+\tilde{X}_{0}
$$

where

$$
C=\beta_{\perp}\left(\alpha_{\perp}^{\prime} \Gamma \beta_{\perp}\right)^{-1} \alpha_{\perp}^{\prime}=\tilde{\beta}_{\perp} \alpha_{\perp}^{\prime}
$$

and $\alpha_{\perp}, \beta_{\perp}$ are the $p \times p-r$ orthogonal complements of $\alpha, \beta$, describing the common stochastic trends, $\alpha_{\perp}^{\prime} \sum_{i=1}^{t} \varepsilon_{i}$, and their loadings, $\tilde{\beta}_{\perp}$.

The baseline model has been carefully checked for signs of mis-specification using a variety of diagnostic tests. According to these, the model seem to describe the data reasonably well. No serious deviations from the basic assumptions of residual independence, heteroscedasticity, and normality were detected. But, of course, complete parameter constancy is hard to guarantee in a period of such significant changes in the macroeconomy. In this sense, the estimates should be interpreted as average effects over the period in question.

\footnotetext{
${ }^{6}$ See Juselius (2006) for a discussion of deterministic components in the cointegrated VAR model.
} 


\subsection{The empirical approach}

The idea here is to expand the information set gradually, at each step building upon previously found cointegration results (see for example Juselius and MacDonald, 2004, 2007 and Juselius, 2007) relying on the invariance of the cointegration property to extensions of the information set: If cointegration is found between a set of variables, this cointegration result will remain valid even if more variables are added to the analysis. Such a gradual approach greatly facilitates the identification of cointegration relations between sets of variables and, additionally, contains useful information about the driving stochastic trends and how they influence the variables.

We shall begin with a VAR analysis of the most important domestic variables, $w-p_{c}, c, U, \Delta p, p_{c}-p_{y}$, and then add the real exchange rate and the long-term interest rate in order to investigate the impact on Spain of the European integration and the increased globalization.

Assume (as we subsequently find) that the cointegration rank is three in the first VAR analysis, and hence, the number of common trends is two. Two new variables added to the previous information set implies three possible cases regarding the cointegration rank.

- $r=3, p-r=4$. The rank is unchanged and the number of autonomous stochastic trends have increased to four. This would imply that the two new variables are neither cointegrated between themselves nor with the five domestic variables. Hence, the two new variables would not add any useful long-run information explaining the Spanish wage, price and unemployment dynamics.

- $r=4, p-r=3$. Adding the two variables have produced one new cointegration relation and introduced one new stochastic trend. The new cointegration relation could either be a relation between real exchange rate and the long-term rate, or a relation between the two new variables and some of the five domestic variables.

- $r=5, p-r=2$. There are two new cointegration relations and no additional common stochastic trend. For example, there could be one cointegration relation between the two new variables, and another one between any of the new variables and some of the domestic variables, or the two new variables are each cointegrated with some of the domestic variables. Whatever the case, the extended model would be driven by the same common stochastic trends as the smaller model.

In this way, the determination of cointegration rank in the extended system contains valuable information about the common stochastic trends that have generated the new variables and how the former are associated with the previously found stochastic trends. 
There is, however, even more information to be gained about the data generating mechanisms by gradually extending the system with one variable at the time. The latter procedure is followed here and the subsequent analysis will be based on: Model 1 containing the five domestic variables, Model 2 adding the real exchange rate to Model 1, Model 3 adding the long-term bond rate to Model 2.

Furthermore, it is also useful to sequentially exploit the information provided by the following two test procedures formulated as hypotheses on $\alpha$ :

1. The tests of a zero row in $\alpha$, i.e. of long-run weak exogeneity. Is the new variable weakly exogenous? Has the previous classification into endogenous and weakly exogenous variables changed?

2. The tests of a unit vector in $\alpha$. Is the new variable purely adjusting? Has the previous classification into purely adjusting/pushing variables changed?

These tests are of particular interest as neither of them are invariant to changes in the information set. Exploiting this feature makes it is possible to learn about the influence of the new variable on the pulling and pushing forces of the system. An additional advantage of the gradual expansion of the information set is that the robustness of the conclusions from a small model regarding the 'ceteris paribus' assumption can be empirically assessed in a systematic way.

\subsection{Determining the cointegration rank}

Table 1 reports three different criteria for the choice of rank: the eigenvalues of the trace test, $\lambda_{i}, i=1, \ldots, p$, the largest unrestricted characteristic root for $r=0,1, \ldots, p$, and the largest $t$ value of $\alpha_{i}, i=1, \ldots, p$. The estimated eigenvalues, $\lambda_{i}$, in the upper part of the table (measuring the squared canonical correlations between the stationary part of the process and $\left.\beta_{i}^{\prime} x_{t}\right)$ show that in all models the smallest $\lambda$ is very close to zero and that the next one is around 0.20 , whereas the remaining ones are relatively large. This corresponds closely to the information in the middle part showing that in all models the largest unrestricted characteristic root for $p-r=0$ is around 0.95 , i.e. very close to the unit circle, whereas the next one is approximately 0.84 . We interpret this to mean that we have one stochastic trend which is very close to a unit root trend, and another which is highly persistent but probably not a 'true' unit root process. This could, for example, describe the long and persistent cyclical movements in the data.

For the choice of $p-r=2$, the largest unrestricted root is 0.81 . The last part of the table shows that for $p-r=2$, there would be at least one significant $\alpha$ coefficient of the last cointegrating relation, insuring against including 
Table 1: Determination of rank in the three models

\begin{tabular}{|c|c|c|c|c|c|c|c|c|}
\hline$p-r$ & 7 & 6 & 5 & 4 & 3 & 2 & 1 & 0 \\
\hline \multicolumn{9}{|c|}{ Eigenvalues $\lambda_{i}$} \\
\hline M1 & & & 0.55 & 0.46 & 0.33 & 0.22 & 0.05 & \\
\hline M2 & & 0.59 & 0.48 & 0.38 & 0.25 & 0.22 & 0.04 & \\
\hline M3 & 0.67 & 0.48 & 0.42 & 0.33 & 0.28 & 0.18 & 0.06 & \\
\hline \multicolumn{9}{|c|}{ 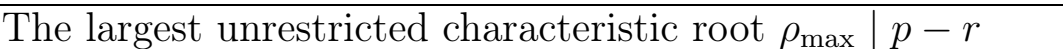 } \\
\hline M1 & & & 0.62 & 0.65 & 0.81 & 0.80 & 0.84 & 0.94 \\
\hline M2 & & 0.62 & 0.63 & 0.82 & 0.83 & 0.83 & 0.84 & 0.95 \\
\hline M3 & 0.63 & 0.65 & 0.68 & 0.82 & 0.81 & 0.81 & 0.83 & 0.95 \\
\hline \multicolumn{9}{|c|}{ The largest absolute $t$-value, $t_{\max }$, of $\alpha_{r}$} \\
\hline M1 & & & & 6.7 & 6.3 & 4.9 & 3.0 & 2.0 \\
\hline M2 & & & 7.9 & 7.8 & 5.0 & 3.9 & 3.8 & 1.2 \\
\hline M3 & & 8.8 & 7.5 & 6.2 & 5.4 & 2.9 & 3.8 & 2.2 \\
\hline
\end{tabular}

These criteria are organized according to the hypothetical number of unit roots in the model as these are invariant to the dimension of the system, whereas the cointegration rank is not. For example, two common stochastic trends in the system corresponds to $r=3$ in M1, $r=4$ in M2 and $r=5$ in M3.

a completely irrelevant cointegration relation in our model. Based on this, we consider the choice of two common stochastic trends to be an appropriate choice for all three models. The interpretation is that the five domestic variables and the two new variables are fully integrated and we can expect the domestic variables to be cointegrated with the two new variables.

\subsection{Tests of pulling and pushing properties}

The test of a zero row in $\alpha$ (a pushing variable) and the test of a unit vector in $\alpha$ (a pulling variable) depend crucially on a correct choice of rank. The test statistics in Table 2 are based on $r=3$ in Model 1, $r=4$ in Model 2, and $r=5$ in Model 3, all of them consistent with $p-r=2$.

The first part of Table 2 shows that while none of the variables can be considered pushing (weakly exogenous) in Model 1, productivity and the price wedge have a much lower test statistic than the other variables. In Model 2, the test statistic for productivity does not change, whereas the real exchange rate, rather than the price wedge, is now close to being weakly exogenous. In Model 3, the result for productivity is again unchanged, but the long-term interest rate has now replaced real exchange rate as 'almost' weakly exogenous.

Thus, cumulated shocks to productivity seem to be one of the common driving forces in this period. Cumulated shocks to the internal price wedge is the other driving force in the small model, but is replaced by the real ex- 
Table 2: Testing a zero row and a unit root in $\alpha$

\begin{tabular}{|c|c|c|c|c|c|c|c|}
\hline & $w-p_{c}$ & $c$ & $U$ & $\Delta p$ & $p_{c}-p_{y}$ & $q$ & $R_{b}$ \\
\hline \multicolumn{8}{|c|}{ Testing a zero row in $\alpha$ (weak exogeneity) } \\
\hline \multicolumn{8}{|c|}{$\mathrm{M} 1(r=3, p-r=2)$} \\
\hline $\begin{array}{l}\chi^{2}(3) \\
{[p v a l]}\end{array}$ & $\begin{array}{l}23.33 \\
{[0.00]}\end{array}$ & $\begin{array}{l}9.24 \\
{[0.03]}\end{array}$ & $\begin{array}{l}38.98 \\
{[0.00]}\end{array}$ & $\begin{array}{l}41.88 \\
{[0.00]}\end{array}$ & $\begin{array}{l}8.92 \\
{[0.03]}\end{array}$ & - & - \\
\hline \multicolumn{8}{|c|}{$\mathrm{M} 2(r=4, p-r=2)$} \\
\hline $\begin{array}{l}\chi^{2}(4) \\
{[p v a l]}\end{array}$ & $\begin{array}{l}24.77 \\
{[0.00]}\end{array}$ & $\begin{array}{l}9.25 \\
{[0.06]}\end{array}$ & $\begin{array}{l}39.34 \\
{[0.00]}\end{array}$ & $\begin{array}{l}41.25 \\
{[0.00]}\end{array}$ & $\begin{array}{l}18.37 \\
{[0.00]}\end{array}$ & $\begin{array}{l}\mathbf{9 . 9 2} \\
{[0.04]}\end{array}$ & - \\
\hline \multicolumn{8}{|c|}{$\mathrm{M} 3(r=5, p-r=2)$} \\
\hline $\begin{array}{c}\chi^{2}(5) \\
{[\text { pval }]}\end{array}$ & $\begin{array}{c}39.14 \\
{[0.00]} \\
\end{array}$ & $\begin{array}{c}10.60 \\
{[0.06]}\end{array}$ & $\begin{array}{c}52.70 \\
{[0.00]}\end{array}$ & $\begin{array}{c}54.57 \\
{[0.00]}\end{array}$ & $\begin{array}{c}26.16 \\
{[0.00]}\end{array}$ & $\begin{array}{l}17.58 \\
{[0.00]}\end{array}$ & $\begin{array}{c}11.40 \\
{[0.04]}\end{array}$ \\
\hline \multicolumn{8}{|c|}{$\begin{array}{l}\text { Testing a unit vector in } \alpha \text { (pure adjustment) } \\
\text { M1 }(r=3, p-r=2)\end{array}$} \\
\hline $\begin{array}{l}\chi^{2}(2) \\
{[p v a l]}\end{array}$ & $\begin{array}{l}4.46 \\
{[0.11]}\end{array}$ & $\begin{array}{l}26.39 \\
{[0.00]}\end{array}$ & $\begin{array}{l}10.35 \\
{[0.01]}\end{array}$ & $\begin{array}{l}5.83 \\
{[0.05]}\end{array}$ & $\begin{array}{l}14.85 \\
{[0.00]}\end{array}$ & - & - \\
\hline \multicolumn{8}{|c|}{$\mathrm{M} 2(r=4, p-r=2)$} \\
\hline $\begin{array}{l}\chi^{2}(2) \\
{[p v a l]}\end{array}$ & $\mathbf{1 . 3 7}$ & $\begin{array}{l}17.29 \\
{[0.00]}\end{array}$ & $\begin{array}{l}\mathbf{3 . 3 0} \\
{[0.19]}\end{array}$ & $\begin{array}{l}3.35 \\
{[0.19]}\end{array}$ & $\begin{array}{l}5.24 \\
{[0.07]}\end{array}$ & $\begin{array}{l}3.68 \\
{[0.16]}\end{array}$ & - \\
\hline \multicolumn{8}{|c|}{$\mathrm{M} 3(r=5, p-r=2)$} \\
\hline $\begin{array}{c}\chi^{2}(2) \\
{[p v a l]}\end{array}$ & $\begin{array}{l}\mathbf{1 . 1 6} \\
{[0.56]}\end{array}$ & $\begin{array}{c}21.81 \\
{[0.00]}\end{array}$ & $\begin{array}{l}5.74 \\
{[0.06]}\end{array}$ & $\begin{array}{l}\mathbf{3 . 7 0} \\
{[0.16]}\end{array}$ & $\begin{array}{l}4.66 \\
{[0.10]}\end{array}$ & $\begin{array}{l}\mathbf{2 . 7 8} \\
{[0.25]}\end{array}$ & $\begin{array}{l}5.18 \\
{[0.07]} \\
\end{array}$ \\
\hline
\end{tabular}

change rate in Model 2, and finally by the long-term interest in Model 3 . The interpretation is that the permanent shocks to the price wedge have originated from the permanent shocks to real exchange rates, which have originated from shocks to the long-term interest rate.

The second part of Table 2 shows that the real consumer wages and the inflation rate seem to have been purely adjusting in all three models. The price wedge can be borderline accepted as purely adjusting in Model 2 and Model 3 , suggesting that it has essentially adjusted to the real exchange rate and the long-term interest rate ${ }^{7}$. The finding that productivity remained weakly exogenous and that real wages and inflation remained purely adjusting when adding new variables is a valuable piece of information about the underlying pulling and pushing forces of the system.

Finally, the joint test of a unit vector in $\alpha$ in Model 3 of real wages, inflation rate, the price wedge and the real exchange rate was accepted based on $\chi^{2}(8)=$ $9.66[0.29]$.

\footnotetext{
${ }^{7}$ The result that $q$ and $R^{l}$ also seem to be almost purely adjusting may seem more puzzling. As explained in Juselius (2007, p.202), such a result can easily arise in a situation when the variable in question only adjusts to one $\beta$ relation, and not very significantly so.
} 
Table 3: An identified $\beta$ structure for the domestic variables

\begin{tabular}{|c|c|c|c|c|c|c|c|c|c|}
\hline & \multicolumn{8}{|c|}{ Model 1: $\chi^{2}(6)=4.01(0.68)$} & \multirow[b]{2}{*}{ trend } \\
\hline & $w^{r}$ & $c$ & $U$ & $\Delta p$ & $p p$ & $D s 86.1$ & $D s 92.3$ & Ds99.1 & \\
\hline$\hat{\beta}_{1}^{c}$ & $\begin{array}{c}-\mathbf{0 . 1 3} \\
{[-6.12]}\end{array}$ & $\begin{array}{l}\mathbf{0 . 1 3} \\
{[6.12]}\end{array}$ & $\begin{array}{l}\mathbf{0 . 1 2} \\
{[4.34]}\end{array}$ & $\begin{array}{l}1.00 \\
{[N A]}\end{array}$ & - & - & $\begin{array}{c}\mathbf{0 . 0 0} \\
{[2.95]}\end{array}$ & - & - \\
\hline$\hat{\alpha}_{1}^{c}$ & $\begin{array}{l}0.59 \\
{[1.38]} \\
\end{array}$ & * & $*$ & $\begin{array}{c}-\mathbf{0 . 8 6} \\
{[-8.19]}\end{array}$ & $\begin{array}{c}-\mathbf{0 . 4 1} \\
{[-3.07]} \\
\end{array}$ & & & & \\
\hline$\hat{\beta}_{2}^{c}$ & $\begin{array}{l}\mathbf{1 . 0 0} \\
{[N A]}\end{array}$ & - & $\begin{array}{l}\mathbf{0 . 2 4} \\
{[2.34]}\end{array}$ & - & - & $\begin{array}{c}-\mathbf{0 . 0 3} \\
{[-3.16]}\end{array}$ & - & $\begin{array}{l}\mathbf{0 . 0 5} \\
{[4.40]}\end{array}$ & $\begin{array}{l}-\mathbf{0 . 0 0} \\
{[-18.57]}\end{array}$ \\
\hline$\hat{\alpha}_{2}^{c}$ & $\begin{array}{c}-\mathbf{0 . 6 5} \\
{[-5.61]} \\
\end{array}$ & $*$ & $*$ & $*$ & $\begin{array}{c}-\mathbf{0 . 1 1} \\
{[-3.17]}\end{array}$ & & & & \\
\hline$\hat{\beta}_{3}^{c}$ & - & $\begin{array}{c}\mathbf{- 1 . 6 5} \\
{[-6.40]}\end{array}$ & $\begin{array}{l}\mathbf{1 . 0 0} \\
{[N A]}\end{array}$ & - & $\begin{array}{c}-\mathbf{0 . 5 7} \\
{[-4.18]}\end{array}$ & $\begin{array}{c}\mathbf{0 . 1 0} \\
{[3.93]}\end{array}$ & $\begin{array}{c}-\mathbf{0 . 2 6} \\
{[-8.10]}\end{array}$ & - & $\begin{array}{l}\mathbf{0 . 0 2} \\
{[8.72]}\end{array}$ \\
\hline$\hat{\alpha}_{3}^{c}$ & $*$ & $\begin{array}{l}\mathbf{0 . 0 7} \\
{[2.97]}\end{array}$ & $\begin{array}{c}-\mathbf{0 . 0 6} \\
{[-7.68]}\end{array}$ & $\begin{array}{c}-\mathbf{0 . 0 3} \\
{[-3.47]}\end{array}$ & $*$ & & & & \\
\hline
\end{tabular}

\section{Sequential identification of cointegrated rela- tions for wage, price, and unemployment}

In the first subsection, we shall first focus on a careful econometric analysis of the complicated interactions between productivity improvements, real wage growth, inflation and unemployment with the aim of identifying the BalassaSamuelson effect as well as the effect of the increased product market competition in the transition period. By including the real exchange rates and the long-term interest rate in the information set we are able to isolate the additional effect of these variables on the transmission mechanisms.

\subsection{Domestic determinants}

The structure of "irreducible" cointegration relations reported in Table 3 contains six over-identifying restrictions which were accepted based on a p-value of 0.68. The structure is generically and empirically identified as defined in Johansen and Juselius (1994) and further elaborated in Juselius (2007, Chapter 12). Whether the estimated relations are also economically identified in the sense of having interpretable coefficients will be discussed at the background of Sections 2 and 3.

The first two relations are essentially describing co-movements between real wages and the unemployment rate, but with opposite signs. Thus, we will give them a first interpretation as affordable and acceptable wage relations describing the relative power of the employers' and the employees' unions as a function of the unemployment rate, the inflation rate and the productivity growth. The first relation can be interpreted as an affordable wage relation describing that demand for labor is low when real wages corrected for productivity are high and that it is positively related to the level of inflation rate. The estimated 
$\alpha$ coefficients, however, show that the adjustment take place foremost in the inflation rate. Because of this, we choose to normalize on inflation rate and obtain a modified Philips curve relationship:

$$
\Delta p_{t}=\underset{[-4.3]}{-0.12} u_{t}+\underset{[6.1]}{0.13}\left(w_{t}^{r}-c_{t}\right) \underset{[-3.0]}{-0.00} D s 923_{t}
$$

The changes of the inflation rate is significantly equilibrium error correcting to this relation, whereas not unemployment rate $^{8}$, consistent with the original idea by Phillips (1958). The interpretation of (11) is that the Phillips curve mechanism is triggered off for different levels of real wage costs. As discussed in Section 2, Spain has in this period experienced different inflation/unemployment regimes (similarly as most of Europe), starting with a period of high real wage costs, inflation and unemployment rates, followed by the more recent period of lower rates. As these regimes have been long lasting, labor market behavior adjusted to what could be called the normal level of unemployment ${ }^{9}$. The estimated step dummy $D s 923_{t}$ suggests that the inflation rate decreased significantly after the speculative attack in 1992:3 in spite of the large devaluation of the peseta.

The second relation, interpretable as an acceptable wage relation, essentially describes that real wage pressure, measured as trend-adjusted real wage, tends to decrease when unemployment increases. The estimated $\alpha$ coefficients shows that it is real wages and the price wedge that are adjusting.

$$
w_{t}^{r}=\underset{[-2.3]}{-0.24} u_{t}+\underset{[3.2]}{0.03} D s 861_{t} \underset{[-4.4]}{-0.05} \mathrm{Ds} 991_{t}+\underset{[8.1]}{0.0035 \text { trend }}
$$

The negative and significant coefficient to unemployment rate indicates that it was the rising levels of unemployment rates from the beginning of the nineties until 1995 that finally stopped real wage claims (in excess of a average annual wage growth rate of approximately 1.4\%). The step dummies show that the level of real wages, given the unemployment rate, increased with $3 \%$ from 1986:1 to 1999:1, but declined below its previous level after 1999:1. Altogether, it provides evidence of a strong trade-off between unemployment and real wage pressure.

The third relation corresponds closely to the hypothetical relation in (6). It shows that the unemployment rate has been co-moving with trend-adjusted productivity and the price wedge. The first effect is assumed to be the consequence of laying off a fraction of the labor force and not hiring new workers

\footnotetext{
${ }^{8}$ When real exchange rate and the bond rate are added to the VAR, unemployment also shows significant equilibrium correction.

${ }^{9}$ This is sometimes discussed under the label hysteresis.
} 
in an attempt to improve labor productivity in a period of strong competitive pressure. The step dummies show that the level of unemployment given productivity and the price wedge, decreased significantly in 1986-1992, but rose again to a higher level in the period after 1992. Normalizing on the unemployment rate we obtain:

$$
u_{t}=\underset{[6.4]}{1.65 c_{t}}+\underset{[4.2]}{0.57 p p_{t}} \underset{[-3.9]}{-0.10} D s 861_{t}+\underset{[8.1]}{0.26} D s 923_{t}+\underset{[8.7]}{0.02 t r e n d}
$$

The estimated $\alpha$ coefficients in Table 3 show that the unemployment rate is strongly equilibrium correcting to this relation, and that productivity and inflation rate are also adjusting. The strong adjustment in unemployment rate is consistent with the hypothetical reaction pattern of a highly exposed industry discussed in Section 3.2. It suggests that the less productive part of the labor force has been laid off to improve productivity.

\subsection{Adding the real exchange rate and the long-term bond rate}

Section 3 suggested that the impact of globalization should hypothetically be associated with the real exchange rate and the long-term interest rate. This is investigated in Model 2, by adding real exchange rate to Model 1 and in Model 3 by adding the bond rate to Model 2 .

\subsubsection{The two new $\beta$ relations}

Though the cointegration property theoretically is invariant to extensions of the variable set, empirically the estimated coefficients may change to some extent. By keeping the previously identified relations unchanged when extending the model with a new variable, we are able to isolate the effect on the system from this variable. As a check of the sensitivity of the results, the cointegration estimates of all three models are reported in the Appendix, Table 6. The basic message is that the estimates of the first three relations are very similar in the three models, but the precision increases to some extent when adding the new variables.

The forth relation, describing the first 'new' cointegration relation obtained when adding the real exchange rate, relates inflation rate to the real exchange rate according to the hypothesis in (7). Thus, the Spanish inflation rate has been equilibrium correcting primarily to the EU price level represented by the German price. The real exchange rate coefficient is significant but very small, indicating slow adjustment. As shown by the estimated step dummy effect, the big devaluation of the peseta after the speculative attack in 1992:3 lowered inflation rate significantly (cf. (11)). 


$$
\Delta p_{t}=\underset{[-3.91]}{0.01 q_{t}}-\underset{[6.02]}{0.01} D s 92.3_{t}
$$

The fifth relation is obtained when adding the long-term bond rate to the system. It is a relation between inflation, unemployment, real exchange rate and the long-term bond rate, which can be interpreted as a relation for either the long-term interest rate, inflation rate, or real exchange rate as all of them show significant equilibrium error correction (see Appendix, Table 7). Normalizing on the interest rate gives:

$$
R_{b, t}=\underset{[5,3]}{0.54} \Delta p_{t}+\underset{[5.9]}{0.12} u_{t}-\underset{[6.5]}{0.05}\left(q_{t}+p p_{t}\right)
$$

showing that the level of the long-term bond rate is positively related with inflation rate and unemployment rate and negatively with real exchange rate formulated in output prices. These are all plausible coefficients; the positive coefficients on unemployment rate can be seen as a consequence of government debt financing of the high unemployment rates that has characterized the transition period to full EMU membership; the negative coefficient on real exchange rate suggests a partial IKE effect, consistent with Johansen, et al. (2007).

Normalizing on the inflation rate instead gives:

$$
\Delta p_{t}=-0.22 u_{t}+1.85 R_{b, t}+0.9\left(q_{t}+p p_{t}\right)
$$

showing that the relation can also be interpreted as a modified Phillips curve relation, where the NAIRU is a function of the long-term interest rate (see Phelps, 1994) and the real exchange rate.

\subsubsection{The adjustment dynamics}

While the cointegration property should be (and was shown to be) reasonably invariant to changes in the information set, this is not necessarily the case with the adjustment coefficients (Juselius, 2007, Chapter 12, 13, Møller, 2008). It is, therefore, of some interest to investigate the effect on the adjustment dynamics when adding the real exchange rates and the bond rate to the system. For instance, do the adjustment dynamics of the 'domestic' variables change, are there feed-back effects from the new variables onto the 'domestic' variables and do the 'domestic relations' have an impact on the new variables. Table 7 in the Appendix reports the estimated $\alpha$ coefficients in the three models.

1. The adjustment coefficients to the first relation, the "affordable wage"/Phillips 
curve relation, changes to some extent in Models 2 and 3 compared to Model 1: even though the inflation rate is significantly adjusting in all three models, the magnitude of the coefficients change. Also, unemployment rate becomes significantly equilibrium correcting in Models 2 and 3 and the real exchange rate has depreciated when ecm $1>0$.

2. The adjustment dynamics of the second relation, the "acceptable wage" relation, are essentially unchanged, indicating that this is a mechanism that is robust to the ceteris paribus assumption.

3. Unemployment rate and productivity are both equilibrium correcting to the third relation in all three models. In addition, inflation rate goes down when unemployment is above its benchmark value $(e \mathrm{~cm} 3>0)$ in Models 1 and 2, whereas the effect of adding the bond rate is that real wages, rather than inflation rate, decrease.

4. The real exchange rate is significantly equilibrium correcting to the forth relation, but also the internal price wedge and unemployment rate are reacting when ecm $4>0$. The estimates are very similar in Models 2 and 3. Finally, the bond rate, real exchange rate, as well as the inflation rate and the unemployment rate are all equilibrium correcting to ecm5, but real wages tend to decrease when ecm $5>0$.

Altogether, the "domestic" adjustment dynamics were reasonably robust to the addition of the "external" variables. Most of the globalization effects seem to take place through the two 'new' relations describing the association between the long-term interest rate and real exchange rate on one hand and domestic inflation, real wages and unemployment rate on the other.

\section{The effect of joining the EU: the dynamics of wage, price, and unemployment}

Section 4.4 demonstrated that four of our seven variables were purely adjusting ("endogenous" in this system) implying that there exists two linear combinations between the remaining three variables that are pushing the system (the "exogenous" forces). The aim of the empirical analysis of this section is twofold, first to identify the two exogenous forces and how they have influenced the variables of the system, second to discuss the structure of feed-back mechanisms after the system has been pushed away from equilibrium by exogenous shocks.

\subsection{The pushing forces}

The common trends representation reported in Table 4 is derived under the "joint unit vector in $\alpha$ " restriction of real wages, inflation rate, the price wedge 
Table 4: The estimated driving forces

\begin{tabular}{|c|c|c|c|c|c|c|c|c|}
\hline & $\hat{\varepsilon}_{w^{r}}$ & $\overline{\hat{\varepsilon}_{c}}$ & $\hat{\hat{\varepsilon}_{u}}$ & $\hat{\varepsilon}_{\Delta p}$ & $\overline{\overline{\varepsilon_{p p}}}$ & $\hat{\varepsilon}_{q}$ & $\hat{\varepsilon}_{R_{b}}$ & trend \\
\hline$\hat{\alpha}_{\perp .1}^{\prime}$ & 0.00 & -0.07 & 0.06 & 0.00 & 0.00 & 0.00 & 1.00 & \\
\hline$\hat{\alpha}_{\perp .2}^{\prime}$ & 0.00 & 0.93 & 1.00 & 0.00 & 0.00 & 0.00 & 0.00 & \\
\hline \multicolumn{9}{|c|}{ The long-run impact matrix $\mathrm{C}$} \\
\hline$w^{r}$ & 0.0 & $\begin{array}{l}0.10 \\
{[0.65]}\end{array}$ & -0.17 & 0.0 & 0.0 & 0.0 & $\begin{array}{l}\mathbf{- 1 . 9 5} \\
{[-4.14]}\end{array}$ & 0.004 \\
\hline$c$ & 0.0 & $\begin{array}{l}\mathbf{0 . 3 4} \\
{[2.10]}\end{array}$ & $\begin{array}{l}0.31 \\
{[1.52]}\end{array}$ & 0.0 & 0.0 & 0.0 & $\frac{-0.41}{[-0.80]}$ & 0.007 \\
\hline$u$ & 0.0 & $\begin{array}{l}-0.29 \\
{[-1.11]}\end{array}$ & $\begin{array}{l}0.11 \\
{[0.33]}\end{array}$ & 0.0 & 0.0 & 0.0 & $\begin{array}{l}3.01 \\
{[3.65]}\end{array}$ & -0.002 \\
\hline$\Delta p$ & 0.0 & $\frac{-0.02}{[-1.20]}$ & $\begin{array}{l}0.00 \\
{[0.20]}\end{array}$ & 0.0 & 0.0 & 0.0 & $\begin{array}{l}0.21 \\
{[3.51]}\end{array}$ & -0.000 \\
\hline$p p$ & 0.0 & $\underset{[-2.17]}{-\mathbf{2 . 2 7}}$ & $\begin{array}{c}-\mathbf{2 . 4 9} \\
{[-1.89]}\end{array}$ & 0.0 & 0.0 & 0.0 & $\begin{array}{l}-0.31 \\
{[-0.09]}\end{array}$ & 0.007 \\
\hline$q$ & 0.0 & $\begin{array}{l}0.76 \\
{[1.07]}\end{array}$ & $\begin{array}{c}-0.33 \\
{[-0.37]}\end{array}$ & 0.0 & 0.0 & 0.0 & $\begin{array}{c}-8.34 \\
{[-3.69]}\end{array}$ & -0.007 \\
\hline$R_{b}$ & 0.0 & $\begin{array}{l}0.04 \\
{[0.47]}\end{array}$ & $\begin{array}{l}0.21 \\
{[1.96]}\end{array}$ & 0.0 & 0.0 & 0.0 & 1.20 & -0.000 \\
\hline
\end{tabular}

and the real exchange rate, explaining the zero columns of the shocks to these variables in the $\mathrm{C}$ matrix (10). Consistent with the test of weak exogeneity in Table 2, the first common stochastic trend, $\hat{\alpha}_{\perp .1}^{\prime} \sum \varepsilon_{i}$, is approximately measured by the cumulated shocks to the long-term bond rate. Its long-run impact on the variables of the system appears from the last column of the $\mathrm{C}$ matrix. A positive shock to the long-term interest rates has a negative long-run impact on real wages and real exchange rates (an appreciation) and a positive impact on unemployment, and inflation. It has no significant effect on productivity and the price wedge. The second stochastic trend, $\hat{\alpha}_{\perp .12}^{\prime} \sum \varepsilon_{i}$, is roughly measured by the sum of the empirical shocks to productivity and unemployment. The long-run impact of these two shocks appear from the second and third column of the $\mathrm{C}$ matrix. It appears that a productivity shock has a negative effect on the price wedge (and a positive effect on itself), but insignificant effects on the remaining variables. An unemployment shock has a significant negative long-run impact on the price wedge and a significant positive impact on the long-term bond rate and productivity, though the latter is not highly significant.

The last column of Table 4 reports the estimated slope coefficients of the linear deterministic trends in the data. It is notable that the trend in productivity is exactly the same as the trend in the price wedge and in the real appreciation of the peseta. This is exactly what the Balassa-Samuelson theory would predict.

Thus, the two stochastic driving forces seems to be associated with shocks to the long-term interest rate and shocks to trend-adjusted productivity and unemployment. The former seems to be very close to a "true" unit root trend 
and is likely to describe the impact of capital liberalization and speculative (imperfect knowledge) behavior in the foreign exchange market. The latter seems to describe the very persistent long cyclical movements in the data and is likely to describe the effect of product market competition in the sample period. Finally, the long-run deterministic trend is likely to describe the Balassa-Samuelson effect. In the next section we shall investigate the mechanisms that have pulled the system back to steady-state after these exogenous shocks.

\subsection{The pulling forces}

Table 5 reports a parsimonious representation of the short-run adjustment structure for the full seven-dimensional model. Lagged productivity, unemployment, and real exchange rate were found to be insignificant in the system (based on F-tests) and were removed altogether prior to imposing 57 cross equation restrictions (based on $\chi^{2}(57)=63.2[0.27]$ ). The short-run dynamic adjustment to the estimated long-run equilibrium relations, reported in the first part of the table, is likely to contain the most important information about where in the system the most significant adjustment has taken place as a consequence of Spain's decision to join the EU. The subsequent discussion will focus on this part.

The adjustment of the Spanish economy from a relatively poor outsider towards today's prosperous EU insider is an example of a highly complicated, dynamic, interrelated multidimensional process (cf. Colander, 2008) and it is empirically challenging to interpret the information in Table 5. To make the major mechanisms more transparent, we shall organize the discussion around the two major common trends described in Table 4 and how these have activated adjustment processes in the labor market.

\subsubsection{The dynamic adjustment associated with the cost of long- term capital}

According to Table 4, the most important of the driving forces seemed to be the cost of capital measured by the cumulated shocks to the bond rate. However, the column for $\Delta R^{l}$ in Table 5 shows that the bond rate has been significantly equilibrium correcting (with a tiny coefficient) to ecm $5,{ }^{10}$ whereas it has not been affected by any of the other determinants of this system. Thus, in this period (with basically free capital movements from 1989 onwards), the longterm bond rate, though marginally affected by labor market disequilibria, was for practical purposes outside domestic policy control (see also Juselius and Toro, 2005).

\footnotetext{
${ }^{10}$ This explains the borderline acceptance of the bond rate as weakly exogenous in Table 2.
} 
Table 5: The short-run dynamics

\begin{tabular}{|c|c|c|c|c|c|c|c|}
\hline & $\Delta w_{t}^{r}$ & $\Delta c_{t}$ & $\Delta u_{t}$ & $\Delta^{2} p_{t}$ & $\Delta p p_{t}$ & $\Delta q_{t}$ & $\Delta R_{t}^{l}$ \\
\hline $\begin{array}{c}\text { ecm } 1_{t-1} \\
{[\text { Phillips.c. } 1]}\end{array}$ & - & - & $\begin{array}{l}-1.52 \\
(-6.8)\end{array}$ & $\begin{array}{c}-0.68 \\
(-8.7)\end{array}$ & $\begin{array}{l}-1.87 \\
(-4.2)\end{array}$ & $\begin{array}{l}-5.63 \\
(-4.1)\end{array}$ & - \\
\hline $\begin{array}{l}\text { ecm } 2_{t-1} \\
\text { [Wage rel.] }\end{array}$ & $\begin{array}{c}-0.66 \\
(-8.0)\end{array}$ & - & - & $\begin{array}{l}0.06 \\
(3.0)\end{array}$ & $\begin{array}{l}-0.15 \\
(-5.3)\end{array}$ & - & - \\
\hline $\begin{array}{l}\text { ecm } 3_{t-1} \\
\text { [unem.prod.] }\end{array}$ & $\begin{array}{l}-0.08 \\
(-3.3)\end{array}$ & $\begin{array}{l}0.06 \\
(4.5)\end{array}$ & $\begin{array}{l}-0.03 \\
(-5.3)\end{array}$ & - & - & $\begin{array}{l}-0.12 \\
(4.0)\end{array}$ & - \\
\hline $\begin{array}{l}e c m 4_{t-1} \\
{[\inf . p p p]}\end{array}$ & - & - & $\begin{array}{l}1.86 \\
(8.5)\end{array}$ & - & $\begin{array}{l}1.51 \\
(3.4)\end{array}$ & $\begin{array}{l}4.26 \\
(3.2)\end{array}$ & - \\
\hline $\begin{array}{l}\text { ecm5 } 5_{t-1} \\
{[\text { Phillips.c. } 2]}\end{array}$ & $\begin{array}{l}0.91 \\
(3.6)\end{array}$ & - & $\begin{array}{l}-0.12 \\
(-2.5)\end{array}$ & $\begin{array}{l}-0.31 \\
(-5.7)\end{array}$ & - & $\begin{array}{l}1.23 \\
(4.5)\end{array}$ & $\begin{array}{l}0.05 \\
(2.7)\end{array}$ \\
\hline$\Delta w_{t-1}^{r}$ & - & - & $\begin{array}{l}-0.04 \\
(-2.6)\end{array}$ & $\begin{array}{l}-0.05 \\
(-2.7)\end{array}$ & - & $\begin{array}{l}-0.28 \\
(-3.0)\end{array}$ & - \\
\hline$\Delta^{2} p_{t-1}$ & $\begin{array}{l}-1.12 \\
(-4.4)\end{array}$ & - & $\begin{array}{l}-0.15 \\
(-2.6)\end{array}$ & - & - & - & - \\
\hline$\Delta p p_{t-1}$ & $\begin{array}{l}-0.72 \\
(-3.3)\end{array}$ & - & - & - & $\begin{array}{l}0.26 \\
(3.2)\end{array}$ & - & - \\
\hline$\Delta R_{t-1}^{l}$ & - & - & $\begin{array}{l}-0.55 \\
(-3.0) \\
\end{array}$ & $\begin{array}{c}-0.59 \\
(-2.4)\end{array}$ & $\begin{array}{c}-0.44 \\
(1.5)\end{array}$ & - & $\begin{array}{l}0.51 \\
(5.5) \\
\end{array}$ \\
\hline$D p 86.1$ & $\begin{array}{l}0.06 \\
(3.9)\end{array}$ & - & - & $\begin{array}{l}0.02 \\
(4.0)\end{array}$ & $\begin{array}{l}0.04 \\
(7.7)\end{array}$ & - & - \\
\hline$D p 92.3$ & - & - & $\begin{array}{l}0.01 \\
(2.6)\end{array}$ & - & - & $\begin{array}{l}0.10 \\
(5.2)\end{array}$ & $\begin{array}{c}0.003 \\
(2.1)\end{array}$ \\
\hline Dp95.1 & - & $\begin{array}{l}0.02 \\
(2.5)\end{array}$ & - & - & - & $\begin{array}{l}0.10 \\
(5.3)\end{array}$ & - \\
\hline Dp99.1 & - & - & $\begin{array}{l}-0.01 \\
(-3.3)\end{array}$ & - & - & - & - \\
\hline$D p 01.1$ & - & $\begin{array}{l}0.03 \\
(3.3) \\
\end{array}$ & $\begin{array}{c}-0.03 \\
(-8.3) \\
\end{array}$ & - & - & - & - \\
\hline
\end{tabular}

That the bond rate had a very significant impact on many of the key domestic variables is evident both from the significant long-run impact coefficients in the last column of Table 4 and from the adjustment coefficients in the rows of $e c m 5_{t-1}$ and $\Delta R_{b, t-1}$ in Table 5 . The adjustment coefficients of ecm 5 show that the real exchange rate, the inflation rate and the unemployment rate have been equilibrium correcting, whereas real wages have been negatively affected (whereas not equilibrium correcting) when ecm $5>0$. All this is in close correspondance with the results in Table 4.

In particular, the result that an increase in the long-term bond rate has been associated with a real exchange rate appreciation is important as it suggests that free capital movements have worked in a direction that aggravated the competitive pressure on Spanish industry ${ }^{11}$. The latter interpretation is supported by noticing that the final impact of an interest rate shock on the

\footnotetext{
${ }^{11}$ In most of the transition period, the shocks to the bond rate were positive. The comovements of the long-term interest with the inverse of the real exchange rate is consistent with the IKE hypothesis.
} 
rest of the system was increasing unemployment and decreasing real wages.

\subsubsection{The dynamic adjustment associated with product market com- petition and the Balassa-Samuelson effect}

Based on Table 4 the second driving force in this period is measured by cumulated shocks to trend-adjusted productivity and the unemployment rate. However, the column of $\Delta c_{t}$ in Table 5 shows that productivity is essentially exogenous, as it does not react on any of the determinants, except ecm 3 to which it is equilibrium correcting ${ }^{12}$. The latter is consistent with the interpretation of (6) in Section 3.3. Because, an exposed enterprise first has to lay off part of the labor force (the least productive part) before it can gain higher labor productivity we would expect unemployment shocks to come first and then productivity adjustment. With quarterly observations such a causal chain can be difficult to identify empirically, explaining the combined productivity and unemployment shocks of the second trend.

Consistent with the above, Table 4 shows that a positive shock to unemployment has improved productivity, lowered the price wedge, and increased the long-term bond rate. The latter effect is likely to reflect the government need to finance the raising unemployment ${ }^{13}$. A positive shock to trend-adjusted productivity has had a similar long-run impact on the system, except no significant impact on the long-term bond rate.

The row of ecm 3 in Table 5 shows that both unemployment and productivity have been significantly equilibrium correcting, that real wage pressure has declined and real exchange has appreciated when ecm $3>0$, i.e. when unemployment has been above its benchmark values. The column of $\Delta w_{t}^{r}$ shows that real wage pressure has declined as a result of ecm $3>0$, ecm $5>0$, and ecm $2>0$. The latter is due to strong equilibrium correcting behavior to an acceptable real wage relation with a strong and negative unemployment effect. When ecm $2>0$, inflation rate and output prices relative to consumer prices start increasing. Thus, ecm 2 seems to describe a standard wage-priceunemployment spiral, whereas ecm 3 and ecm 5 are associated with product price competition and its effect on labor demand.

\subsubsection{Inflation adjustment}

The final question is by which means inflation rate was brought down to the European rates. First, ecm4 associating the Spanish inflation rate with the

\footnotetext{
${ }^{12}$ Again, this is consistent with the borderline acceptance of productivity as weakly exogenous in Table 2.

${ }^{13}$ This is likely to be one of the main reasons why the European level of long-term bond rates was so high in this period which was characterized by very high levels of unemployment rates in most European countries.
} 
real exchange rates provides clear evidence that Spanish prices over the long run have converged towards a sustainable European PPP level (proxied by the German prices). The estimated adjustment coefficients in the row of ecm 4 suggest that unemployment has increased and real exchange rate depreciated when $e c m 4>0$, i.e when inflation rate has deviated from this long-run path. Thus, the interpretation seems to be that the slow inflation convergence to PPP primarily resulted in increased unemployment. The long swings of the real exchange rates in the transition period due to the appreciation of the peseta is likely to have aggravated this long-run convergence.

The adjustment coefficients in the inflation column $\Delta^{2} p_{t}$ of Table 5 shows that the steady decrease of the inflation rate towards the European inflation level took place through two medium-run type of Phillips curve mechanisms, ecm 1 and $e c m 5^{14}$. The former describes an affordable real wage/NAIRU relation in which NAIRU is a function of the real wage level corrected for productivity. The latter describes the unemployment / inflation curve trade-off as a function of the long-term bond rate and the real exchange rate. Table 5 shows that inflation is strongly equilibrium correcting (as is unemployment, the bond rate and real exchange rate) and that real wages adjust downwards when unemployment and inflation is above the steady state.

\section{Conclusions}

Based on a cointegrated VAR analysis this paper has investigated the wage, price, and unemployment dynamics in Spain during the period 1983:3 to 2007:3, a period which approximately coincides with the Spanish convergence process towards the European level of inflation rates, interest rates, and purchasing power parity. The following broad findings can be emphasized as being particularly important for understanding the mechanisms behind the success of the Spanish convergence from an relatively poor outsider to a prosperous EU insider:

1. Real wages claims in excess of productivity growth seem to have resulted in increased unemployment rather than price inflation.

2. Unemployment has been co-moving with trend-adjusted productivity and the price wedge as a consequence of product market competition.

3. In the long-run, price inflation has adjusted to the real exchange rates (the external price wedge). At the end of the period this adjustment process has brought the Spanish inflation rate in line with the European

\footnotetext{
${ }^{14} \mathrm{~A}$ slightly surprising result is that $e c m 4$ does not appear in the column of $\Delta^{2} p_{t}$. This is probably because the inflation convergence was utterly slow, as evidenced by the tiny coefficient of $q$ in ecm4.
} 
level. The tendency of the Spanish peseta to appreciate with high levels of Spanish long-term bond rate has prolonged the convergence.

4. Evidence of two types of Phillips-curve relationship was found in the data; one when controlling for different levels of real wages, inflation and unemployment, i.e. controlling for high and low inflation regimes, the other when controlling for the level of long-term bond rate and the real exchange rate.

5. Adjustment in the change of the inflation rate was achieved via the two "modified" Phillips-curve relationships, thus reducing inflationary pressure in the medium-run.

6. Unemployment rates have come significantly down at the end of the period as a result of real wage restraints, of a competitive level of real exchange rates, and a low level of interest rate.

We think the results contain important lessons to be learnt for the new EU member states. First of all, it seems crucial to maintain high competitiveness in the tradable sector in order to achieve a successful convergence towards the European purchasing power parity level. The increase in consumption wages and consumer prices as a result of the Balassa-Samuelson effect should not be allowed to exceed the improvement in productivity. Second, before fixing the real exchange rate it seems crucial that it is on its sustainable (competitive) purchasing power parity level. Third, there does not seem to be a short-cut to a European level of standard of living: the path to sustainable prosperity seems to follow the path of productivity improvement. Forth, excessive real wage increases seem to lead to increasing unemployment, slowdown in productivity growth, higher interest rates, and loss of competitiveness. On the other hand, the access to the European market and the possibility of increased export demand is likely to speed up the convergence process as long as competitiveness is not eroded by excess wage increases.

\section{References}

Balassa, B. (1964): "The purchasing-power parity doctrine: A reappraisal", Journal of Political Economy, vol. 72, no. 6, pp. 584-596.

Banerjee, A. and B. Russell (2005): "Inflation and measures of the markup", Journal of Macroeconomics, vol. 27, pp. 289-306.

Boeri, T., A. Brugiavini and L. Calmfors (2001): The Role of Unions in the Twenty-First Century, Oxford University Press, Oxford. 
Colander, D. (2008): "The Economy as an Evolving Complex System III: Current Perspectives and Future Directions", Economica, vol. 75, pp. 191202.

Frydman, R. and M.D. Goldberg (2007): "The dollar-euro exchange rate and the limits of knowledge", Center on Capitalism and Society Working Paper, No 22, Columbia University.

Johansen, S. and K. Juselius (1994): "Identification of the long-run and the short-run structure an application to the ISLM model", Journal of Econometrics, vol. 63, pp. 7-36.

Johansen, S., K. Juselius, R. Frydman and M.D. Goldberg (2007): "Testing Hypotheses in an I(2) Model with Applications to the Persistent Long Swings in the Dmk/USD Rate", Discussion Papers 07-34, University of Copenhagen. Department of Economics.

Juselius, K. (2003): "Wage, price, and unemployment dynamics and the convergence to purchasing power parity in the Euro area", Discussion Paper 03-01, Institute of Economics. University of Copenhagen.

Juselius, K. (2006): The cointegrated VAR model. Methodology and applications, Oxford University Press.

Juselius, K. (2007): The Cointegrated VAR Model. Methodology and Applications, Oxford University Press, Oxford.

Juselius, K. and J. Toro (2005): "Monetary transmission mechanisms in Spain: The effect of monetization, financial deregulation, and the EMS", Journal of International Money and Finance, vol. 24, pp. 509-531.

Juselius, K. and R. MacDonald (2004): "International parity relationships between the USA and Japan", Japan and the World Economy, vol. 16, pp. 1734.

Juselius, K. and R. McDonald (2007): "International parity conditions: A joint modelling approach", in International Macro-economics: Recent Developments, edited by A. M.-Z. ), Nova Science Publishers.

Moeller, N. (2008): "Bridging Economic Theory Models and the Cointegrated VAR Model", Submitted to the open access, open assessment journal Economics.

Moene, K. O., M. Wallerstein and M. Hoel (1993): "Bargaining structure and economic performance", in Trade Union Behaviour, Pay Bargaining and Economic Performance, edited by Flanagan R.J., Moene K.O. and M. Wallerstein, FIEF and Oxford University Press. 
Phelps, E. S. (1994): Structural Slumps: The Modern Equilibrium Theory of Unemployment, Interest, and Assets, Harvard University Press.

Phillips, A. (1958): "The relation between unemployment and the rate of change on money in the United Kingdom, 1861-1957", Economica, vol. 25, pp. 283-299.

Samuelson, P. (1964): "Theoretical notes on trade problems", Review of Economics and Statistics, vol. 46, no. 2, pp. 145-154. 
8 Appendix 
Table 6: Sequential identification of the long-run beta relations

\begin{tabular}{|c|c|c|c|c|c|c|c|c|c|c|}
\hline \multicolumn{2}{|c|}{ M1: $\chi^{2}(6)=4.01(0.68$} & \multicolumn{5}{|c|}{ M2: $\chi^{2}(10)=6.45(0.78)$} & \multicolumn{4}{|c|}{ M3: $\chi^{2}(12)=12.62(0.40)$} \\
\hline$w^{r}$ & $c$ & $U$ & $\Delta p$ & $p p$ & $q$ & $R_{b}$ & Ds86.1 & $D s 92.3$ & Ds99.1 & trend $^{1}$ \\
\hline \multicolumn{11}{|c|}{$\hat{\beta}_{1}:$ A modified Phillips curve } \\
\hline $\begin{array}{l}-\mathbf{0 . 1 3} \\
{[-6.12]}\end{array}$ & $\begin{array}{l}\mathbf{0 . 1 3} \\
{[6.12]}\end{array}$ & $\begin{array}{l}\mathbf{0 . 1 2} \\
{[4.34]}\end{array}$ & $\begin{array}{l}\mathbf{1 . 0 0} \\
{[N A]}\end{array}$ & - & - & - & - & $\begin{array}{l}\mathbf{0 . 0 0} \\
{[2.95]}\end{array}$ & - & - \\
\hline $\begin{array}{l}-\mathbf{0 . 0 6} \\
{[-9.08]}\end{array}$ & $\begin{array}{l}\mathbf{0 . 0 6} \\
{[9.08]}\end{array}$ & $\begin{array}{l}\mathbf{0 . 0 4} \\
{[5.50]}\end{array}$ & $\begin{array}{l}\mathbf{1 . 0 0} \\
{[N A]}\end{array}$ & - & - & - & - & $\begin{array}{l}\mathbf{0 . 0 1} \\
{[4.59]}\end{array}$ & - & - \\
\hline $\begin{array}{l}-\mathbf{0 . 0 6} \\
{[-9.73]}\end{array}$ & $\begin{array}{l}\mathbf{0 . 0 6} \\
{[9.73]}\end{array}$ & $\begin{array}{l}\mathbf{0 . 0 4} \\
{[5.39]}\end{array}$ & $\begin{array}{l}\mathbf{1 . 0 0} \\
{[N A]}\end{array}$ & - & - & - & - & $\begin{array}{l}\mathbf{0 . 0 1} \\
{[4.54]}\end{array}$ & - & - \\
\hline \multicolumn{11}{|c|}{$\hat{\beta}_{2}: \mathrm{A}$ wage relation } \\
\hline $\begin{array}{l}\mathbf{1 . 0 0} \\
{[N A]}\end{array}$ & - & $\begin{array}{l}\mathbf{0 . 2 4} \\
{[2.34]}\end{array}$ & - & - & - & - & $\begin{array}{l}-\mathbf{0 . 0 3} \\
{[-3.16]}\end{array}$ & - & $\begin{array}{l}\mathbf{0 . 0 5} \\
{[4.40]}\end{array}$ & $\begin{array}{l}-\mathbf{0 . 0 0} \\
{[-18.57]}\end{array}$ \\
\hline $\begin{array}{l}1.00 \\
{[N A]}\end{array}$ & - & $\begin{array}{l}\mathbf{0 . 2 9} \\
{[3.10]}\end{array}$ & - & - & - & - & $\begin{array}{l}-\mathbf{0 . 0 3} \\
{[-3.56]}\end{array}$ & - & $\begin{array}{l}\mathbf{0 . 0 5} \\
{[4.78]}\end{array}$ & $\begin{array}{l}-\mathbf{0 . 0 0} \\
{[-19.48]}\end{array}$ \\
\hline $\begin{array}{l}1.00 \\
{[N A]}\end{array}$ & - & $\left.\begin{array}{l}0.31 \\
{[3.24]}\end{array}\right]$ & - & - & - & - & $\begin{array}{l}-\mathbf{0 . 0 4} \\
{[-5.00]}\end{array}$ & - & $\begin{array}{l}\mathbf{0 . 0 5} \\
{[5.07]}\end{array}$ & $\begin{array}{l}-\mathbf{0 . 0 0} \\
{[-19.19]}\end{array}$ \\
\hline \multicolumn{11}{|c|}{$\hat{\beta}_{3}:$ Unemployment and competitiveness } \\
\hline M1: & $\begin{array}{l}-\mathbf{1 . 6 5} \\
{[-6.40]}\end{array}$ & $\begin{array}{l}\mathbf{1 . 0 0} \\
{[N A]}\end{array}$ & - & $\begin{array}{l}-\mathbf{0 . 5 7} \\
{[-4.18]}\end{array}$ & - & - & $\begin{array}{l}\mathbf{0 . 1 0} \\
{[3.93]}\end{array}$ & $\begin{array}{r}-\mathbf{0 . 2 6} \\
{[-8.10]}\end{array}$ & - & $\begin{array}{l}\mathbf{0 . 0 2} \\
{[8.72]}\end{array}$ \\
\hline M2: & $\begin{array}{l}-\mathbf{2 . 2 0} \\
{[-6.92]}\end{array}$ & $\begin{array}{l}1.00 \\
{[N A]}\end{array}$ & - & $\begin{array}{l}-\mathbf{0 . 5 8} \\
{[-3.48]}\end{array}$ & - & - & $\begin{array}{l}\mathbf{0 . 1 3} \\
{[4.10]}\end{array}$ & $\begin{array}{l}-\mathbf{0 . 3 3} \\
{[-7.88]}\end{array}$ & - & $\begin{array}{l}\mathbf{0 . 0 2} \\
{[8.63]}\end{array}$ \\
\hline M3: & $\begin{array}{l}-\mathbf{2 . 8 1} \\
{[-7.98]}\end{array}$ & $\begin{array}{l}\mathbf{1 . 0 0} \\
{[N A]}\end{array}$ & - & $\begin{array}{l}-\mathbf{0 . 4 7} \\
{[-2.52]}\end{array}$ & - & - & $\begin{array}{l}\mathbf{0 . 1 2} \\
{[3.25]}\end{array}$ & $\begin{array}{l}-\mathbf{0 . 4 2} \\
{[-9.10]} \\
\end{array}$ & - & $\begin{array}{l}\mathbf{0 . 0 3} \\
{[9.42]} \\
\end{array}$ \\
\hline \multicolumn{11}{|c|}{$\hat{\beta}_{4}$ : Inflation adjustment (nominal convergence) } \\
\hline M2: & - & - & $\begin{array}{l}\mathbf{1 . 0 0} \\
{[N A]}\end{array}$ & - & $\begin{array}{l}-\mathbf{0 . 0 1} \\
{[-5.52]}\end{array}$ & - & - & $\begin{array}{l}\mathbf{0 . 0 1} \\
{[6.02]}\end{array}$ & - & - \\
\hline M3: & - & - & $\begin{array}{l}1.00 \\
{[N A]}\end{array}$ & - & $\begin{array}{l}-\mathbf{0 . 0 2} \\
{[-6.57]}\end{array}$ & - & - & $\begin{array}{l}\mathbf{0 . 0 1} \\
{[6.08]}\end{array}$ & - & - \\
\hline \multicolumn{11}{|c|}{$\hat{\beta}_{5}:$ Modified Phillips cure 2} \\
\hline- & - & $\begin{array}{l}\mathbf{0 . 2 2} \\
{[5.78]}\end{array}$ & $\begin{array}{l}\mathbf{1 . 0 0} \\
{[N A]}\end{array}$ & $\begin{array}{l}-\mathbf{0 . 0 6} \\
{[-5.26]}\end{array}$ & $\begin{array}{l}-\mathbf{0 . 0 9} \\
{[-6.33]}\end{array}$ & $\begin{array}{r}-1.84 \\
{[-10.99]}\end{array}$ & - & - & - & - \\
\hline
\end{tabular}

${ }^{1}$ The trend has been scaled by a factor of 100 . 
Table 7: The adjustment dynamics and the specific-to-general

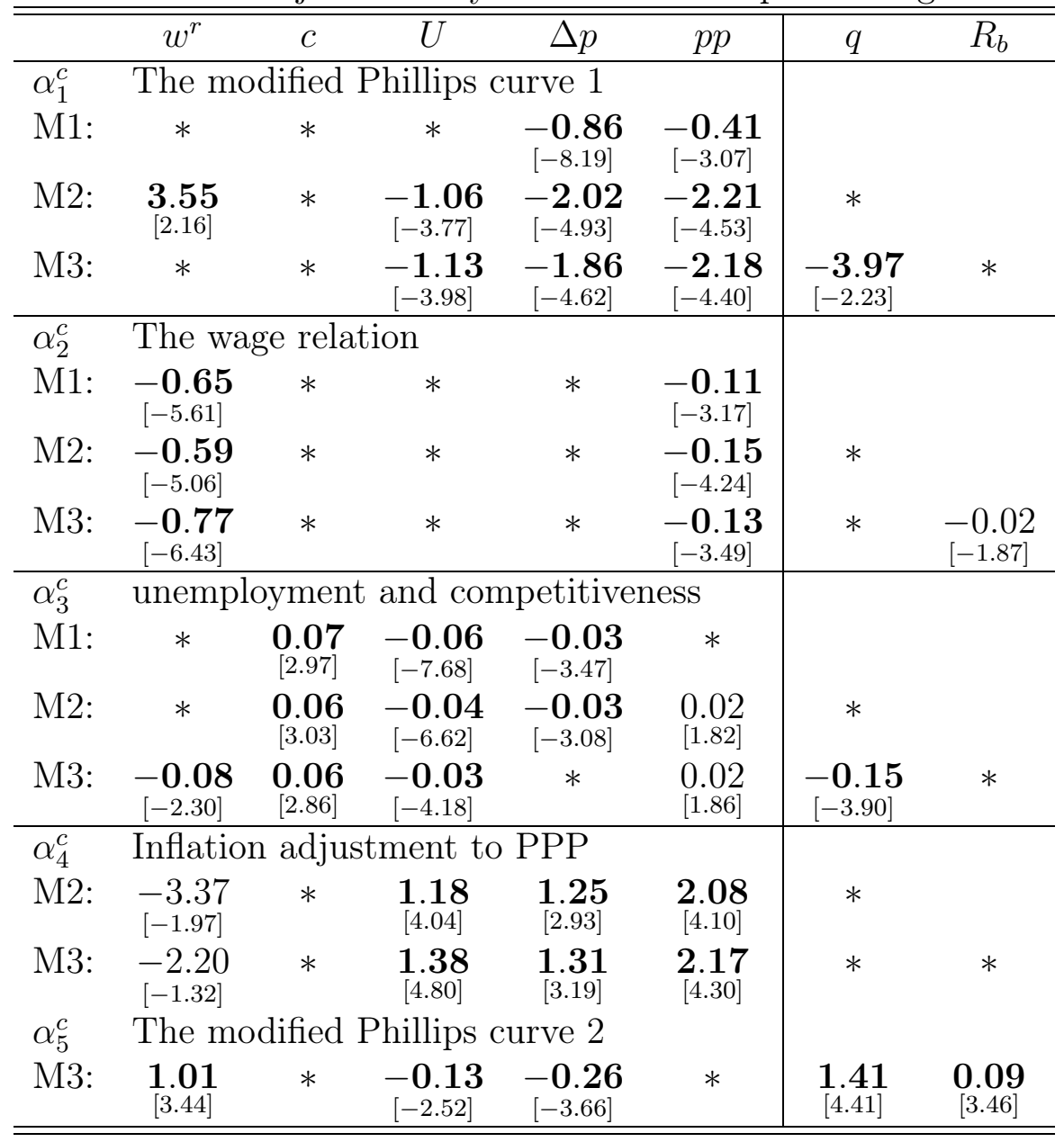

